\title{
Leadership competences for the excellence of municipalities' strategic management
}

\author{
Andrius Valickas \\ Department of Management, Mykolas Romeris University \\ Lithuania \\ avalickas@mruni.eu \\ Agota Giedre Raišiene \\ Department of Management, Mykolas Romeris University \\ Lithuania \\ agotar@mruni.eu \\ Malvina Arimavičiūtè \\ Department of Management, Mykolas Romeris University \\ Lithuania \\ arimaviciute@gmail.com
}

\begin{abstract}
Specifics of leadership in municipalities is significantly influenced by the complexity of municipal management, which is happening in multi-layer administration environment, with various interested parties and administrative actors involved at the same time. Formalized strategic planning system in Lithuanian municipalities assures the implementation of governmental and regional strategies, however, certain inner strategic problems of the municipalities remain unsolved. The purpose of this article is to reveal the peculiarities of strategic management in Lithuanian municipalities and to define leadership competences in strategic management processes. Benchmarking, generalisation and synthesis are used as the research methods here. The model of leadership competences suggested by the authors can be used by Lithuanian municipalities seeking to establish more transparent selection of candidates for municipal posts, more objective evaluation of their activities, accurate identification of personnel professional development needs. The most important result of proper leadership application is more efficient and effective functioning of strategic planning processes at the municipal level as leadership enables filling in the gaps between formalized structures and procedures, it also opens new opportunities for strategic planning.
\end{abstract}

Keywords: municipality, strategic planning, strategic management system, leadership

JEL Classification: H70, H73 


\section{INTRODUCTION}

Strategic management processes in municipalities are mainly determined by changes and conflicts happening in the political and social-economic environment of a country. Social and economic development of a country is inevitably raising certain tensions between authorities and the general public (Domarkas, 2005). Increase of social tension and conflicts, existing paradoxes and changes due to globalization are implied by social and economic differences (Raipa, 2008). The major conflict inherent to strategic management in Lithuanian municipalities is the one between governmental regional policy, which is implemented according to a certain priority order, and the main purpose and criteria of municipality establishment - i.e., preparation to manage and supervise the environment, communal infrastructure, to provide services for population of a municipality and to perform other functions according to the Lithuanian law on municipalities.

Hierarchical municipal organizations are usually full of managerial and organizational problems. Managers and administrators lack appropriate monitoring and motivation mechanisms to encourage employees to perform in tune with the mission of a municipality. The legal basis of the formalized strategic planning system in Lithuanian municipalities assures the implementation of government and regional strategies, however, some inner problems of these municipalities remain unsolved. In trying to solve these problems it is not sufficient to reveal methodical shortcomings in strategic planning, supervision and evaluation, but it would be also necessary to explore the possibilities for human resources better performance of their duties entrusted to them by the local citizens. Currently, there is no clear division of functions and responsibilities among the leaders in terms of strategic management in Lithuanian municipalities provided by the legal acts regarding municipalities' functions and competences of municipal institutions (municipality council, director of municipality administration, mayor, headman). In many of Lithuanian municipalities insufficient attention is payed to strategic planning function: there is no responsible department or even a single civil servant who would devote his/her attention to strategic-level problems of a municipality, including satisfaction of the community's needs. In such a situation the main role must be played by the leaders solving local problems of a municipality and making rational and legally nonregulated decisions.

The purpose of this article is to reveal the peculiarities of strategic management in Lithuanian municipalities and to define the leadership competences in their strategic management processes. The objectives of the article are: i) to analyse the specifics of strategic management at the municipal level in Lithuania; ii) to explore the importance of leadership in the context of Lithuanian municipalities; iii) to ground leadership competences in strategic management processes of Lithuanian municipalities. Benchmarking, generalisation and synthesis will be used as the scientific methods in order to achieve the stated purpose.

\section{SPECIFICS OF STRATEGIC MANAGEMENT AND IMPORTANCE OF LEADERSHIP IN THE LITHUANIAN MUNICIPALITIES}

Scholars are interpreting differently the importance of leadership in preparation of strategy. As it is noted by H. Mintzberg, B. Ahlsrand and J. Lampel (1998) the schools of design and entrepreneur approach towards strategy preparation are highlighting the strongest relation between organizational strategy and leadership. The authors claim that the importance of leadership in preparing and implementing strategy depends on the complexity of the managed entity. If the managed entity is not complex, there is no need for leadership efforts for its management.

However, the Lithuanian municipalities are quite complex objects due to many reasons. First of all, public administration in the Lithuanian municipalities is happening in several layers management 
environment, where subnational (local authorities), national (central authorities) and global (international organizations) levels can be discerned. Due to multi-level public governance there is no one clear centre of power, which would dictate and control the contents of political and managerial processes and their development and which could be responsible for success and failure of strategic management in the municipalities.

Secondly, strategic management in the Lithuanian municipalities is happening coordinating and aligning the needs of many interested parties (such as the state, economic bodies, the population, nongovernmental organizations and other groups' interests and needs). Moreover, the success of strategic management is influenced not by one leader but by the group of political and administrative level actors such as members of the council of municipality, mayors, headmen, directors of municipal budget enterprises who usually have differing interests.

Thirdly, in contrast to other countries, strategic management in Lithuanian municipalities is happening following to the united methodology defined by the resolution of the government (Government of the Lithuanian Republic, 2014). However, it remains much space for legally non-regulated however important and related to management and rationally grounded strategic decisions especially in the area of programs' preparation and implementation.

Finally, differently from municipalities of many other countries, Lithuanian municipalities apply program based budgetary planning method. Using this method, the major attention seeking for defined aims is paid towards the objectives and results of the programs, also towards financial resources allotted for achievement of the purposes. The practice indicates that this method is suitable for well-functioning strategic management system of the municipality, which is able to operatively react towards environmental changes and to timely form strategic directions and control their implementation. However, the following shortcomings are evident in the majority of the Lithuanian municipalities in the sphere of strategic management systems (Arimavičiūtè, 2012):

- Strategic plans for different periods are not always composing general and united system of the plans;

- Not always sufficient attention is paid towards grounded current situational analysis;

- Not sufficient compatibility of municipalities' strategic planning documents with the provisions of the state strategic planning and EU structural support regulating documents;

- Lack of skills and knowledge specifying the raised aims and objectives, the competences of administrative specialists of municipalities in the area of strategic planning are unsatisfactory;

- Insufficient compatibility of strategic planning documents prepared by municipalities with the budgets of the municipalities;

- Insufficient attention is paid towards continuity of the prepared strategies - the prepared strategies are not regularly reviewed and corrected taking into consideration the changing circumstances.

Numerous strategic planning documents (Figure 1) conditions high mutual relation of strategic planning documents and consequently big administrative burden. Insufficiently assured budget compliance with strategic operating plans: the most often case is that the budgets of municipalities are prepared not following to the approved strategic operating plans, differing budget and strategic operating plan change procedures are applied. Changes of budget are implemented according to the practices established in the municipalities and not on the basis of general principles. 


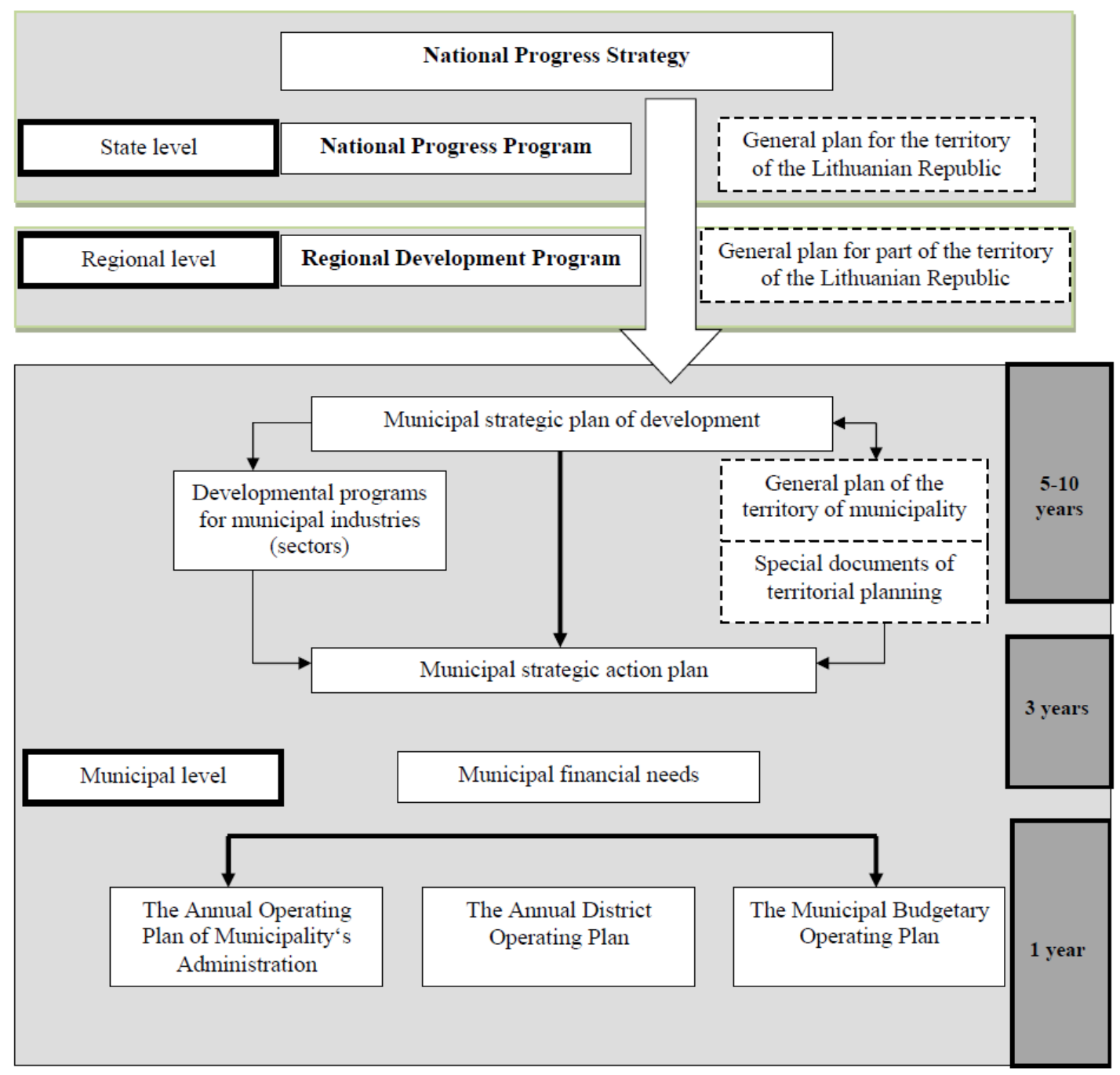

Figure 1. Scheme of strategic planning documents of municipality, pursuant to Resolution No. 1435 of the Government of the Lithuanian Republic of December 15, 2014

In such a situation it is complicated to perform supervision of the programs of municipalities' strategic plan and state budget appropriations allocated to them, to assure activities and funds usage efficiency due to high number and different types of the appropriation governors and their conditional independence. There is no clear division of functions and responsibilities in the sphere of strategic planning. Legal acts regulating local municipalities do not clearly define municipality institutions' (municipal council, director of municipality administration) and the subjects, which are under their direct authority functions and competence in the sphere of strategic planning. In the majority of municipalities insufficient attention is devoted to the function of strategic planning itself: there is no responsible department or even civil servant, in some municipalities just temporary work groups are implementing these strategic tasks.

Seeking to avoid these shortcomings of the Lithuanian municipalities' strategic management system, issuing legal acts the attempts were made to regulate the mutual relation of strategic documents (Figure 2) and to provide the unified strategic planning recommendations for all the municipalities (Government of the Lithuanian Republic, 2014). As the analysis of reports of 60 Lithuanian municipalities on strategic 2014 and 2015 plans indicates that implementation of legal regulation of strategic management in municipalities produced just partial positive changes. 


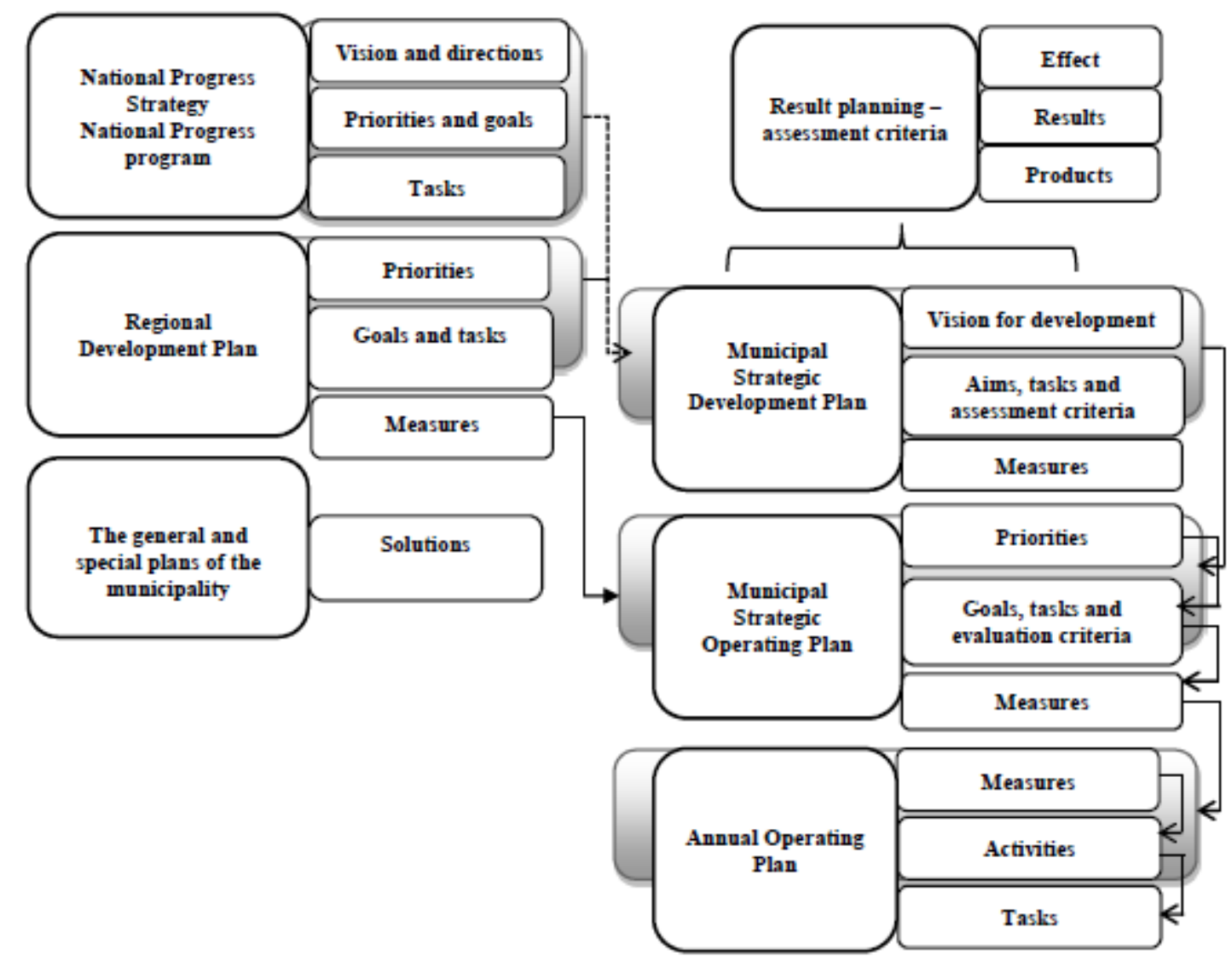

Figure 2. Strategic planning documents and their mutual relation, pursuant to Resolution No. 1435 of the Government of the Lithuanian Republic of December 15, 2014

The united methodology of strategic planning provided all the municipalities with rational relation among strategic plans, supplied the structures of strategic plans and their implementation supervision mechanisms, and assured implementation of the governmental, regional and other higher hierarchy level strategies. However, some inner problems of the municipalities remained insufficiently solved. Preparing strategic plans of the municipalities neither outer nor inner factors are analysed, however Lithuanian municipalities are affected by strong and significant natural, economic, demographical and infrastructural differences in resources, and this essentially determines the disparities in the social and economic situation of separate territories' of the country.

Inner resources, regulation of employment relations, managerial responsibilities, personnel qualification, investments into human capital are also not analysed. In the process of designing separate programs of municipalities strategic purposes are not grounded by concrete problems, possible alternatives are not discussed, causal relations are not determined among the program's aims, tasks, their evaluation criteria and means, which could be considered to be a logical model of the program. Here human resources and especially leaders, who are the main strategists, functions and competence are encountered.

Quatro et al. (2007) in his leadership model defines conceptual thinking as one from other four leadership domains. On the basis of this leaders have to foresee the future, be able to forecast events, their consequences, and to ground the decisions related to the future of the municipality on their insights. One of the main competences of contemporary managers is the ability to create vision and to inspire the employees in the context of permanent changes. It can firmly be stated that changes in the Lithuanian 
municipalities, which are now happening are mostly related to governmental and regional priorities paying least attention to local problems of the municipalities and local visons. Municipal strategic operating plans preparation, discussion and approval cycle (Figure 3) is very complicated, as budget formation applying program based management is integrated with strategic planning process.

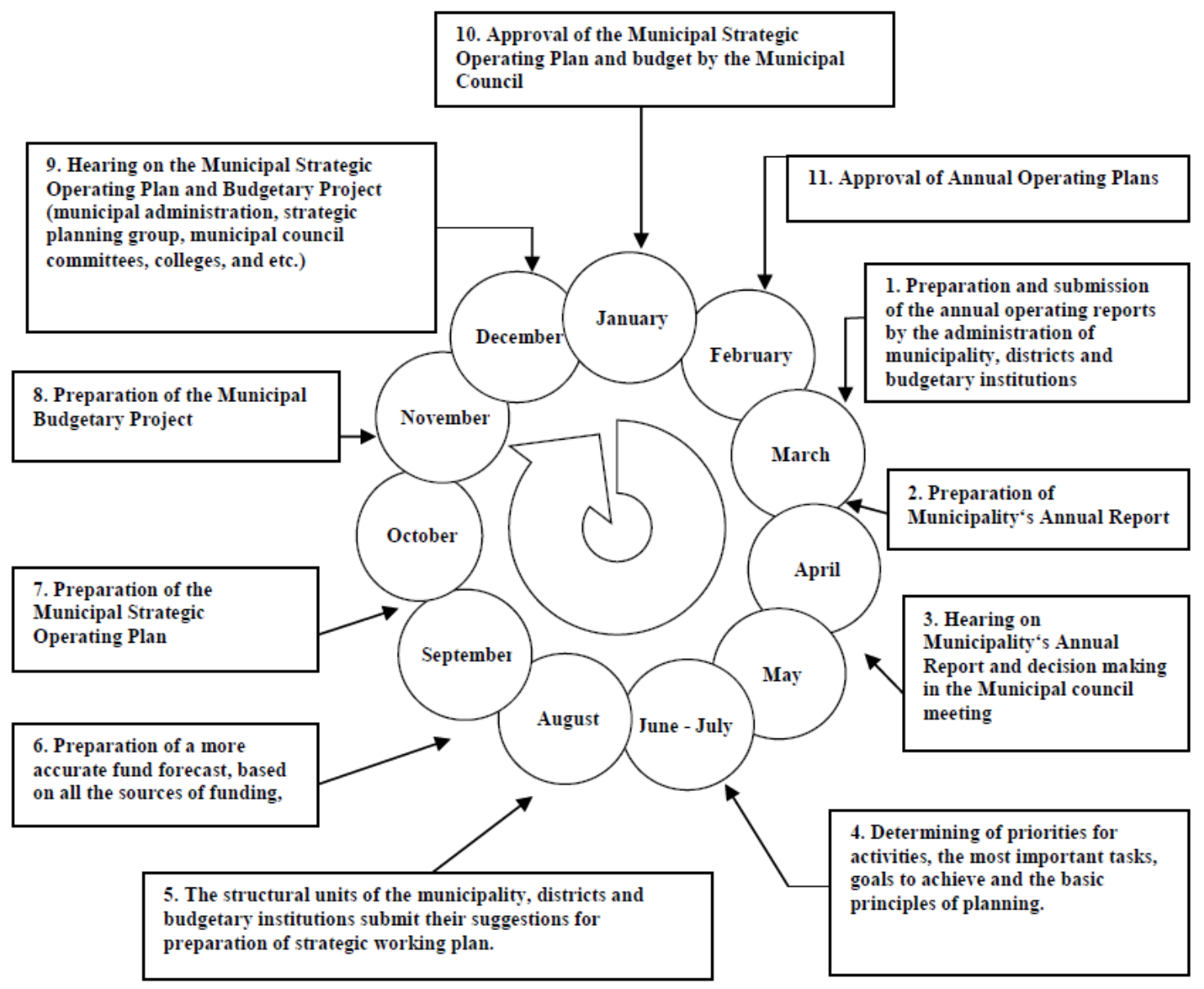

Figure 3. Recommended cycle of municipality strategic operating plan preparation, discussion, approval and report for the implementation results, pursuant to Resolution No. 1435 of the Government of the Lithuanian Republic of December 15, 2014

The documents obligate the municipal institutions (municipality council members, director of municipality administration) and the subjects under their direct authority to perform their functions timely and pursuant to the required competences in the sphere of strategic planning.

\section{LEADERSHIP COMPETENCES AT THE MUNICIPAL LEVEL}

Analysing the changing role of municipal institutions managers in the context of new public governance, the problem of relation between management and leadership phenomena arises. Scholars recognize that in majority spheres of institutional management managerial and administrative competences should be complemented by leadership competences, especially when speaking about strategic management processes. Just interface of management and leadership creates the assumptions for organizational efficiency and effectiveness. D. V. Simonet and R. P. Tett (2013) identify five approaches towards conceptualization 
of management and leadership in relation to each other. The first one is bipolar where leadership and management are depicted as two endpoints on a single continuum. This viewpoint has frequently encouraged the leader -manager debate resulting in multiple popularized lists of traits pertaining to management or leadership thus reinforcing binary distinctions. This approach would entail hiring and training opposite sorts of people to serve as managers versus leaders and limit expectations of promoting from one role to the other (Simonet \& Tett, 2013). The second - unidimensional approach, where leadership equals to management according to its form, process and functions. The manager's daily routine does not conform to the prototypical image of the rational planner. Instead, the manager's role is characterized by reactivity, overload, brevity, variety, and discontinuity. Most planning is informal and intuitive, decision processes are political, and oral interactions are brief. Thus, in the context of dynamic organizational systems, it is difficult to disentangle managers' and leaders' demands and actions (Alvesson \& Sveningsson, 2003). The third approach could be called unidimensional because leadership and management are portrayed as essentially interchangeable. While not explicitly stating the two domains are equivalent, many outstanding works in the history of management and leadership have treated them as an integrated whole (Bennis \& Nanus, 1985; Bass \& Bass, 2008). The fourth - hierarchical (management within leadership). This conceptualization place management within the broader leadership domain (Finkelstein \& Hambrick, 1996). This perspective is also recognized in Wortman's (1982) strategic management functions of executive leadership. The fifth - hierarchical (leadership within management). Leadership is considered to be a subset of the broader concept of management (Boal \& Hooijberg, 2000). A manager typically is responsible for making sure that both appropriate managerial and leadership activities are completed as necessary (Bedeian \& Hunt, 2006). The later approach is very relevant in strategic management processes at the municipal level. This could mean that in the context of municipalities more important are not formal positions of managers and formal legal regulation of strategic management processes, however the ability of municipal leaders to properly use these processes in order to achieve the goals relevant for the municipalities. It is evident that some stages of the cycle of municipal strategic operating plan preparation, discussion, approval and report for implementation results (Figure 3) are hardly fulfilled purely on the basis of administrative means, not invoking leadership as necessary component. However, in practice the situation is often encountered when not having strategic priorities and strategic direction on the municipal level, which is directly caused by the absence of leadership in the municipality, is masked by precise application of formal strategic planning procedures. This situation just indicates prevailing legal administrative approach to strategy at the municipal level.

In the contemporary discourse on public sector leadership characteristics, including municipal level leadership, several essential competences of leaders are identified. The first of them is analytical thinking. Public managers play an important role not just as neutral bureaucrats, but they also have a decisive role and a heavy responsibility to create public value. Leaders should be able to understand institutional and discursive complexities and inconsistencies in a multi-contextual and multi-layered public sector (Pedersen \& Tangkjar, 2013). Communityship, the second competence. The term was coined by Henry Mintzberg. It is basically about how managers are responsible for their own institutions, i.e. municipalities, as a community driven by engagements and strong ethical beliefs and standards, it is a matter of sustainability of public services and organisation, rather than short-sighted beliefs in profit. Authority and legitimacy in the involving municipality are no longer distributed through hierarchies and formal organisational forums, but are to a much higher degree a result of an capability to act, create and relate own organisational effort to complex contexts of politics, strategies, ambiguities and counterproductive expectations from politicians, citizens, employees, partners, enterprises, medias, and so on (Pedersen \& Tangkjar, 2013). The third competence is critical reflexivity. It is more than a matter of technical skills regarding organisation and its management. Critical reflexivity means raising social, political and cultural issues, questioning purposes and 
intentions and, if necessary, challenging the assumptions and taken for-granted-ness on which organizational policies and practices are based (Reynolds, 2011). The last competence, which is very important for municipal leaders in the contemporary institutional contexts, is managination. This means that public strategic leadership is a creative practice that brings forth an action world for public value creation using public, action and transformation images (Thygesen \& Tangkjær, 2005).

The above mentioned universal competences are theoretically identified taking into consideration the realities of the contemporary globalized world. However in different countries different conceptions of leadership competences frameworks in public sector exist (Larat, 2016).

The following leadership competences are used to select and develop public managers in France (Secretariat general du gouvernement, 2011):

- Competences related to action (capacity to decide in complex situations, personal commitment, adaptability, stress resistance);

- Competences related to interpersonal relationships (capacity to convince and mobilise people, capacity to conduct reforms and manage changes, capacity to develop competences and to delegate, communication, capacity to interact with the environment and to cooperate, capacity to advise properly);

- Situational competences (sensitivity for general interest, capacity to develop a strategic vision and to anticipate, open-mindedness and self-criticism, innovation and creativity).

United Kingdom applies the below mentioned leadership competences for different hierarchy level officials. For directors general and directors (Civil Service Human Resource, 2012):

- Developing in-depth insight into the dynamics and issues surrounding the department and government, including political, economic, social, environmental and technological impacts;

- Clarify and shape the department's role and purpose in delivering civil service priorities for the public and economic good;

- Understand where the department sits within and aligns across the civil service;

- Articulate the department's business model and help people see their role within it;

- Create clear long-term strategies focused on adding value to the citizen and making real, lasting change beyond the civil service.

For deputy directors (Civil Service Human Resource, 2012):

- Anticipate and predict the long term impact of national and international developments, including economic, political, environmental, social and technological, on own area;

- Identify and shape how own area fits within and supports the work of the Department;

- Develop an in-depth insight into customers, citizens, services, communities and markets affected by their area and the wider public sector context;

- Create joined up strategies and plans that have positive impact and add value for stakeholders, citizens and communities;

- Shape strategies and plans which help put into practice and support the department's vision and long-term direction, including those shared with other departments.

The following leadership competences are highlighted in the United States public sector (United States Office of Personnel Management, 2012):

- Leading change. This core qualification involves the ability to bring about strategic change, both within and outside the organisation, to meet organisational goals. This requires the ability to establish an organisational vision and to implement it in a continuously changing environment.

- Leading people. This core qualification involves the ability to lead people toward meeting the organisation's vision, mission and goals. This requires the ability to provide an inclusive workplace 
that fosters the development of others, facilitates cooperation and teamwork, and supports constructive resolution of conflicts.

- Results driven. This core qualification involves the ability to meet organisational goals and customer expectations. This requires the ability to make decisions that produce high-quality results by applying technical knowledge, analysing problems and calculating risks.

- Business acumen. This core qualification requires the ability to manage human, financial and information resources strategically.

- Building coalitions. This core qualification requires the ability to build coalitions internally and with other federal agencies, state and local governments, non-profit and private sector organisations, foreign governments or international organisations to achieve common goals.

In Lithuania, implementing the project "Analysis of the competences necessary for civil service and civil servants' posts description catalogue", civil servants' competences model and its application methodology were designed (Chomentauskas \& Dereškevičiūtè, 2014; Adamonienė \& Petrauskienè, 2014). The model is also applicable to civil servants at municipal level. It was suggested that civil service competences model would be composed of three groups of competences:

- General competences (necessary for all the official from all the spheres of activities);

- Managerial and leadership competences (necessary for managing and leading institutions and departments);

- Specific and professional competences (necessary for implementing special functions, related to specific professional fields).

Such selection of groups is based on relevant criteria. It must be noted that just one competence is identified in the area of leadership. It is defined as the example shown for the manager for others, ability of a manager to convey vision, mission, goals and inspire to strive for them, to render necessary emotional support, to involve into decision making, developing employees, creating positive working environment. However, this narrow conception of leadership in comparison to leadership competences definition and specification in other countries is evidently insufficient.

The model does not separately discuss the specifics of leadership at the municipal level. Making deeper analysis of relevant documentation, it can be noted that currently there is even no united system of requirements for analogous posts in Lithuanian civil service. It is not established what concrete knowledge, skills and capabilities must be possessed by municipal officials and politicians taking different posts. Thus, the united system of requirements is necessary for the knowledge, skills and capabilities of municipal officials, on the basis of which more transparent and objective system of selection, evaluations, development of municipal employees would be assured. On the other hand, specificity of strategic planning at the Lithuanian municipal level is very important establishing the competences of municipal institutions' civil servants and politicians. Authors of the article claim that first of all establishing municipal leadership competences it is necessary to base on measurable knowledge, skills and experiences relevant to separate posts, also not rejecting necessary behaviours and personal qualities. Knowledge and skills based leadership competences development approach in the Lithuanian municipalities must be oriented towards concrete positions and their relation to strategic management as it was established by the analysis performed by the authors of this article, taking into consideration international experiences (Table 1). 
Table 1

Leadership competences in the area of municipal strategic management (composed by the authors)

\begin{tabular}{|c|c|}
\hline $\begin{array}{l}\text { Political and } \\
\text { administrative } \\
\text { posts in the } \\
\text { Lithuanian } \\
\text { municipalities }\end{array}$ & $\begin{array}{c}\text { Necessary leadership competences (complementing official requirements and job } \\
\text { descriptions) }\end{array}$ \\
\hline $\begin{array}{l}\text { Member of } \\
\text { municipality council }\end{array}$ & $\begin{array}{l}\text { Ability to identify strategic problems in perspective, to foresee possible directions of activities, } \\
\text { to coordinate agreements with other institutions, solve conflicts relating to strategic problems } \\
\text { and to assure required financial and legal intervention. Members of the council approving all the } \\
\text { strategic plans of the municipality (excluding annual operating plans) and the amendments of } \\
\text { the mentioned plans have to take into consideration global perspective, identity of the } \\
\text { municipality and its uniqueness, seeking to utilize in the most efficient way the resources of the } \\
\text { municipality for the established goals achievement and problems solving. They have to take into } \\
\text { account needs of the communities, be able to create visions and be able to foresee changes } \\
\text { necessary for implementing visions. Political far-sightedness, global thinking, informal } \\
\text { information management, negotiation management, conflict management and influencing are } \\
\text { essential competences. }\end{array}$ \\
\hline $\begin{array}{l}\text { Director of } \\
\text { municipality } \\
\text { administration }\end{array}$ & $\begin{array}{l}\text { Ability to foresee the essential strategic problems of the municipality, their projection in the } \\
\text { strategic plans. Organizational skills preparing strategic planning documents, discussing, } \\
\text { specification in the municipality council, their implementation, supervision of implementation } \\
\text { of strategic planning actions, informing the public about the strategic decisions and actions } \\
\text { made. Conceptual thinking is necessary in foreseeing future events and consequences relevant } \\
\text { for the municipality, approving municipality administration, districts and budget enterprises } \\
\text { annual plans of operation. Analytical skills are important analysing annual activity reports of } \\
\text { districts, budget enterprises and the municipality administration itself. }\end{array}$ \\
\hline $\begin{array}{l}\text { Structural } \\
\text { department/official } \\
\text { of the municipality } \\
\text { administration } \\
\text { responsible for } \\
\text { strategic planning }\end{array}$ & $\begin{array}{l}\text { Ability to prepare strategic plans and to perform their implementation supervision, analysing } \\
\text { causes due to which certain indices are not achieved or achieved just partially. The essential } \\
\text { competence is responsibility for preparation of strategic planning documents, their } \\
\text { implementation supervision and analytical thinking. }\end{array}$ \\
\hline Mayor & $\begin{array}{l}\text { Ability to solve the identified problems, to influence and change social environment relevant to } \\
\text { strategic planning, to redistribute appropriations among the means of implementation and } \\
\text { programs. The most important is responsibility for timely approval of strategic planning } \\
\text { documentation, assurance control of strategic planning documents implementation, timely } \\
\text { reports presentation. Very important are competences of global thinking, ability to create vision } \\
\text { and deliver it properly to the populations, ability to positively influence and unite the community } \\
\text { for common goals. }\end{array}$ \\
\hline $\begin{array}{l}\text { Employees of } \\
\text { municipality } \\
\text { administration } \\
\text { departments }\end{array}$ & $\begin{array}{l}\text { Ability to perform supervision, planning documents or their parts (separate implementation } \\
\text { means / programs) implementation, co-ordinations, evaluating the processes of the } \\
\text { implementation and relevant budget spending, comparing planed and factual indices. The } \\
\text { essential competences are responsibility, ability to organize and analytical thinking. }\end{array}$ \\
\hline Headmen & $\begin{array}{l}\text { Ability to solve strategic problems in the territory of the municipality, providing suggestions for } \\
\text { the strategic operating plan of the municipality and annual plan of the district. Also to objectively } \\
\text { evaluate performance results implementing annual operating plan of the district. Far-sightedness } \\
\text { and intuition regarding suggested means of implementation and organizational abilities are } \\
\text { necessary. }\end{array}$ \\
\hline
\end{tabular}


On the general it can be stated that for the efficient strategic management in the Lithuanian municipalities it is not sufficient for the relevant entities and officials to possess the competences relating to management and leadership which are defined in the civil service competence model and its application methodology, as in the process of strategic management such leadership competences as responsibility, analysis, ability to ground and deliver the decisions to the public, also such specific competences as political far-sightedness, formal and informal information management, negotiation, conflict management, controlling and supervising of strategic planning processes and influencing using not just legal powers but personal characteristics are necessary.

\section{CONCLUSION}

Central to our analysis was the role of leadership in municipalities. Leadership provides a strong strategic direction which has widespread support and commitment from employees at all levels. Specifics of leadership in Lithuanian municipalities is significantly influenced by the complexity of managing municipalities, which is happening in multi-layer administration environment full of interested parties and other administrative level actors, where legal regulation of strategic management and program based management prevail.

Inner problems of municipalities remain insufficiently solved as it is complicated to perform control and supervision of strategic operating plan programmes and related budget appropriations and to assure funds usage efficiency due to big number of different types of appropriations governors, their relative autonomy. There is no clear division of functions and responsibilities in municipalities in the area of strategic planning. The role of municipal leaders in such a context is especially important.

Scientific literature provides different conceptions of management and leadership relation. Hierarchical (leadership within management) model, where leadership is considered to be a subset of the broader concept of management, is the most appropriate to solving strategic management problems at the municipal level. In the context of municipalities very important is ability of municipal leaders to properly use formalized strategic management processes in order to achieve the goals relevant for the municipalities. It is evident that some stages of the cycle of municipal strategic operating plan are impossible to implement not invoking leadership as necessary component. However, in practice the situation is often encountered when not having strategic priorities and strategic direction on the municipal level, which is directly caused by the absence of leadership in the municipality, is masked by precise application of formal strategic planning procedures.

Having admitted the necessity of leadership in municipal strategic planning, it is necessary to define leadership competences relevant to strategic planning in the municipalities. Besides some universal contemporary leadership competences, different countries provide country specific leadership competences models. In Lithuania civil servants' competences model and its application methodology were designed. The model is applicable to civil servants at municipal level. However, the model does not separately discuss the specifics of leadership at the municipal level. Nevertheless, just one competence is identified in the area of leadership. This scares attention to and narrow conception of leadership in comparison to leadership competences definition and specification in other countries is evidently insufficient and harmful for implementation of strategic planning at municipal level. Such leadership competences as responsibility, political far-sightedness, negotiation with interested parties, influencing and conflict management are necessary for different hierarch level officials participating in strategic planning at municipal level.

The model of leadership competences provided by the authors of this article can be used in the Lithuanian municipalities seeking to establish more transparent selection of candidates to municipal officials, more objective evaluation of their activities, more accurate identification of the professional development needs. And the most important result of proper application of leadership is more efficient and effective 
functioning of strategic planning processes on the municipal level. Leadership is at the heart of this organisational culture - it facilitate and empower rather than control or restrict, filling the gaps between formalized structures and procedures it opens new opportunities for strategic planning.

\section{REFERENCES}

Adamonienè, R., \& Petrauskienè, R. (2014). Expression of Strategic Competencies of Leaders in Civil Service: the Case of Municipalities in Lithuania. Human Resources Management \& Ergonomics, 8(2), 6-19.

Alvesson, M., \& Sveningsson, S. (2003). The great disappearing act: difficulties in doing "leadership". The leadership quarterly, 14(3), 359-381.

Arimavičiūtè, M. (2012). Lietuvos savivaldybių strateginio planavimo problemos. Viešoji politika ir administravimas, 11(2), 272-276.

Bass, B. M., \& Bass, R. (2008). The Bass handbook of leadership: Theory, research, and managerial applications. NY: Free Press.

Bedeian, A. G., \& Hunt, J. G. (2006). Academic amnesia and vestigial assumptions of our forefathers. The leadership quarterly, 17(2), 190-205.

Bennis, W., \& Nanus, B. (1985). Leaders: Strategies for taking charge. NY: Harper\&Row.

Boal, K. B., \& Hooijberg, R. (2000). Strategic leadership research: Moving on. The Leadership Quarterly, 11(4), 515-549.

Chomentauskas, G., \& Dereškevičiūte, E. (2014). Valstybès tarnautoju kompetenciju modelis ir jo taikymo metodika. VTD, Baltic printing house.

Civil Service Human Resources. (2012). Civil Competency Framework 2012-2017. CSH Resources.

Domarkas, V. (2005). Viešojo administravimo raidos aktualijos. Viešoji politika ir administravimas, 13, 7-14.

Finkelstein, S., \& Hambrick, D. C. (1996). Strategic leadership: Top executives and their effects on organizations. St. Paul, MN: West.

Larat, F. (2017). Developing an integrated and comprehensive training strategy for public sector leaders: The French experience. Teaching Public Administration, 35(1), 88-104.

Lietuvos Respublikos Vyriausybès nutarimas (Government of the Lithuanian Republic resolution) Nr.1435 „Dél strateginio planavimo savivaldybese rekomendaciju patvirtinimo,, 2014m. gruodžio 15d.

Mintzberg, H., Ahlstrand, B., \& Lampel, J. (1998). Strategy safari: A Guided Tour through the Wilds of Strategic Management. London. Prentice Hall.

Pedersen, D., \& Tangkjær, C. (2013). Building leadership capacity in the involving network state. Teaching Public Administration, 31(1), 29-41.

Quatro, S. A., Waldman, D. A., \& Galvin, B. M. (2007). Developing holistic leaders: Four domains for leadership development and practice. Human Resource Management Review, 17(4), 427-441.

Raipa, A. (2008). Socialiniai pokyčiai ir naujos viešojo valdymo sistemos. Ekonomika ir vadyba: aktualijos ir perspektyvos, 10(1), 127-131.

Reynolds, M. (2011). Reflective practice: origins and interpretations. Action Learning: Research and Practice, 8(1), 5-13.

Secretariat general du gouvernement. (2011). Document cadre Profil des competences manageriales des cadresdirigeants de l'Etat'. Version No. 2.

Simonet, D. V., \& Tett, R. P. (2013). Five perspectives on the leadership-management relationship: a competencybased evaluation and integration. Journal of Leadership \& Organizational Studies, 20(2), 199-213.

Thygesen, N. T, \& Tangkjær, C. (2005). Managerial technologies and the formation of observation. Working paper, Department of Management, Politics and Philosophy, Copenhagen Business School.

United States Office of Personnel Management. (2012). Guide to Senior Executive Service Qualifications. USOPM. Retrieved from https://www.opm.gov/policy-data-oversight/senior-executive-service/referencematerials/guidetosesquals 2012.pdf

Wortman Jr, M. S. (1982). Strategic management and changing leader-follower roles. The Journal of applied behavioral science, 18(3), 371-383. 